\title{
EFFECT OF BLUE LIGHT ON HYPERBILIRUBINAEMIA
}

\author{
BY \\ P. M. G. BROUGHTON, E. J. R. ROSSITER, C. B. M. WARREN, \\ G. GOULIS, and P. S. LORD \\ From St. John's Hospital, Chelmsford; the Department of Medicine, Royal Free Hospital, London; \\ and the Department of Chemical Pathology, University of Leeds
}

(RECEIVED FOR PUBLICATION MARCH 25, 1965)

Neonatal hyperbilirubinaemia, of any cause, is potentially dangerous and may produce kernikterus. The standard method of treatment is by exchange transfusion, carried out as often as necessary to keep the serum bilirubin below an arbitrary danger level of between 20 and $30 \mathrm{mg} . / 100 \mathrm{ml}$. There is, however, no clear evidence that any absolute value in serum bilirubin concentration per se constitutes a danger (Trolle, 1964). On the other hand it seems that certain additional factors, such as prematurity, asphyxia, and the respiratory distress syndrome, may potentiate the toxic action of bilirubin on brain cells (Wood, Culley, Waterhouse, and Powell, 1962). Exchange transfusion is not without risk and, as was suggested by Trolle (1964), the mortality rate from this method of treatment may exceed the incidence of kernikterus. A simpler and safer alternative is, therefore, desirable for cases that are not anaemic.

Cremer, Perryman, and Richards (1958) showed that in some cases of neonatal jaundice the serum bilirubin level could be reduced by exposure of the infant to sunlight or to an artificial blue light. Several groups of South American workers have described their experiences with this method of treatment (Ferreira, Cardim, and Mellone, 1960; Ferreira, Berezin, Barbieri and Larrubia, 1960a, b, c; Mellone, 1960; Peluffo, Beltran, Malinger, Giguens, Vila Vidal, and Lorenzo de Ibarreta, 1962), but it has not found general acceptance, mainly because of doubts as to its effectiveness and ignorance of the nature and possible toxicity of the products of the photochemical decomposition of bilirubin (Franklin, 1958; Blondheim, Zabriskie, and Lathrop, 1962b).

This paper records the results of in vivo and in vitro experiments which were designed to obtain more information about this method of treatment. Its effectiveness in lowering the serum bilirubin was investigated in a clinical trial on a group of infants with neonatal jaundice. Gunn rats have a similar unconjugated hyperbilirubinaemia, due to a deficiency of the enzyme glucuronyl transferase (Lathe and
Walker, 1958), and the effect of blue light on their serum bilirubin levels was also studied. Signs of toxicity were looked for in both infants and rats. Ernster, Herlin, and Zetterström (1957) demonstrated that bilirubin uncoupled the oxidative phosphorylation of brain and liver mitochondria, and suggested that this was the basis of its toxicity. We have examined the possible toxicity of the photochemical decomposition products of bilirubin by studying their effect on oxidative phosphorylation. Biesold, Liebold, and Theile (1962) showed that, in the absence of soluble protein, uncoupling takes place at very low bilirubin concentrations. In order to match the conditions in the newborn infant, our experiments have been conducted in the presence of serum.

\section{Experimental}

Clinical Material and Methods. The results of Cremer et al. (1958) and Perryman (personal communication) suggested that sunlight was more effective than artificial light in reducing serum bilirubin levels, but in Britain the former source is too unpredictable for a clinical trial. We have, therefore, used a light cradle, similar to that described by Cremer et al. (1958), containing 8 light blue fluorescent tubes (G.E.C. Ltd.,) which emit blue light with a peak emission at $480 \mathrm{~m} \mu$, close to the absorption maximum of bilirubin.

The naked infant was placed in a Sorrento cot under this cradle, and the eyes were covered with a simple shield. The infant was turned every hour and the rectal temperature was recorded. This did not exceed $100 \cdot 2^{\circ} \mathrm{F}$. $\left(37.9^{\circ} \mathrm{C}\right.$.) in any of the treated cases. The baby was removed for feeding, and treatment was not restarted until 30 minutes after the completion of the feed. The light exposure was continued for a maximum of 6 hours at a time, with an interval of 2 hours before further treatment.

The work of Cremer et al. (1958) suggested that light treatment was likely to be ineffective when the serum bilirubin was rising rapidly, as in haemolytic disease. It was. therefore, necessary to exclude such cases, and to restrict the trial to infants in whom there was no evidence of haemolytic disease. When light treatment is used in 
an individual case it is difficult to prove that a fall in serum bilirubin level is due to the effect of light, and not to experimental error or physiological variations. A scheme was therefore devised to test whether there were significant differences between a group of infants treated with light, and a similar untreated group. The following criteria were adopted for the selection of cases for this clinical trial.

(1) There was no clinical contraindication to the use of light treatment, e.g.- the use of continuous oxygen or an incubator.

(2) Cases of $\mathrm{Rh}$ haemolytic disease were excluded by choosing only those infants with a negative Coombs' test and a capillary blood haemoglobin level, at the age of more than 24 hours, of not less than $100 \%$ $(13.8 \mathrm{~g} . / 100 \mathrm{ml}$.).

(3) All infants who were selected had a total serum bilirubin level of not less than $12 \mathrm{mg}$. $/ 100 \mathrm{ml}$., with not more than $2.5 \mathrm{mg}$. $/ 100 \mathrm{ml}$. in the conjugated form, at a time which is denoted by the point $\mathrm{A}$ in Fig. 1 . Infants with a rapidly rising serum bilirubin level (e.g. $10 \mathrm{mg} . / 100 \mathrm{ml}$. at the age of 24 hours) were excluded, since these were likely to need an exchange transfusion.

In those infants who fulfilled these criteria a second serum bilirubin estimation was made 12 hours later (point B). If this result was greater than that at $\mathbf{A}$, and not less than $13.0 \mathrm{mg} . / 100 \mathrm{ml}$., the infant was allocated by random selection to either the treated or the control group. Two further serum bilirubin estimations (points C and D) were made at 12-hourly intervals in all cases. Serum bilirubin was measured by the method of Lathe and Ruthven (1958) on blood collected from the heel of the infant.

Treated cases were irradiated with light for about 8 hours during the 12-hour period between points $B$ and $C$. Cases in the control group were nursed in exactly the same way in the same ward, but received no light treatment.

Gunn Rats. Six shaved male Gunn rats, weighing 250350 g., were kept in a cage placed directly under a lamp holder similar to that used for the infants. They were continuously exposed to blue light and received a mean value of $\mathbf{5 3 0}$ foot-candles for $\mathbf{1 0}$ days. The air temperature remained between 26 and $28^{\circ} \mathrm{C}$. Blood was taken from the tail vein before light exposure, and on the 2 nd, 4th, 6th, and 10th days, and the plasma bilirubin concentration was determined using the Malloy and Evelyn method (1937). The changes in plasma level were compared with those observed in 8 male Gunn rats kept under normal laboratory conditions.

Rat Mitochondria. A concentrated bilirubin solution was prepared by the method of Ruthven and Lathe (Rozdilsky and Olszewski, 1961) and contained a molar ratio of bilirubin to bovine albumin of $36: 1$. The solution was diluted with 9.0 volumes of $0.154 \mathrm{M}$ potassium chloride containing $13 \cdot 3 \%(\mathrm{~V} / \mathrm{V})$ fresh human serum, and centrifuged at $15,000 \mathrm{~g}$ for 20 minutes. The clear supernatant was drawn into glass tubes $(600 \mathrm{~mm}$. $\times$ $4 \mathrm{~mm}$.), stoppered at both ends and suspended vertically in front of the blue light source for 32 hours. The diazo test, which is specific for bilirubin, was applied using the Lathe and Ruthven (1958) and the King and Coxon (1950) methods, allowing 1 hour for colour development in the latter. Inorganic phosphate was determined by the method of Fiske and Subbarrow (192.5).

Oxidative phosphorylation was determined according to Lardy and Wellman (1952), using brain and liver mitochondria prepared from male Wistar rats by the method of Aldridge (1957). Each Warburg flask contained mitochondria equivalent to $1 \mathrm{mg}$. nitrogen (liver) or $0.5 \mathrm{mg}$. nitrogen (brain), in $0.2 \mathrm{ml} .0 .25 \mathrm{M}$ sucrose solution, together with $0.8 \mathrm{ml}$. incubation medium $(p H 7 \cdot 6)$ and $3.0 \mathrm{ml}$. light-treated or untreated bilirubin solution. In the control flasks, the bilirubin solution was replaced by $3.0 \mathrm{ml} .13 .3 \%(\mathrm{~V} / \mathrm{V})$ serum in isotonic potassium chloride solution. The incubation medium was similar to that used by Aldridge (1957), supplemented with co-factors for brain mitochondria (Christie, Judah, and Rees, 1953).

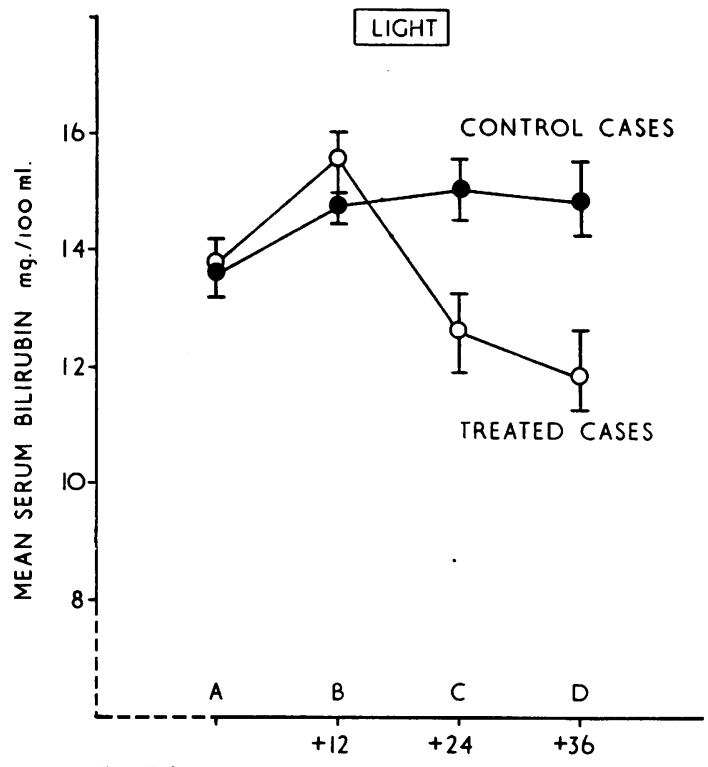

HOURS

FIG. 1.-Mean serum bilirubin levels in treated and control groups of infants. The standard errors of the means are indicated by vertical bars.

\section{Results}

Clinical Trial. The serum bilirubin concentrations of both the treated and the control groups of infants, together with their birth weights, are given in Table 1. If the light treatment is effective the serum bilirubin of the treated infants at Point $C$ (Fig. 1) should be lower than that at B. Individual values of $\mathbf{C}-\mathbf{B}$ for all cases are illustrated in Fig. 2. It can be seen that there is some overlap between these two groups, which is undoubtedly due to the 


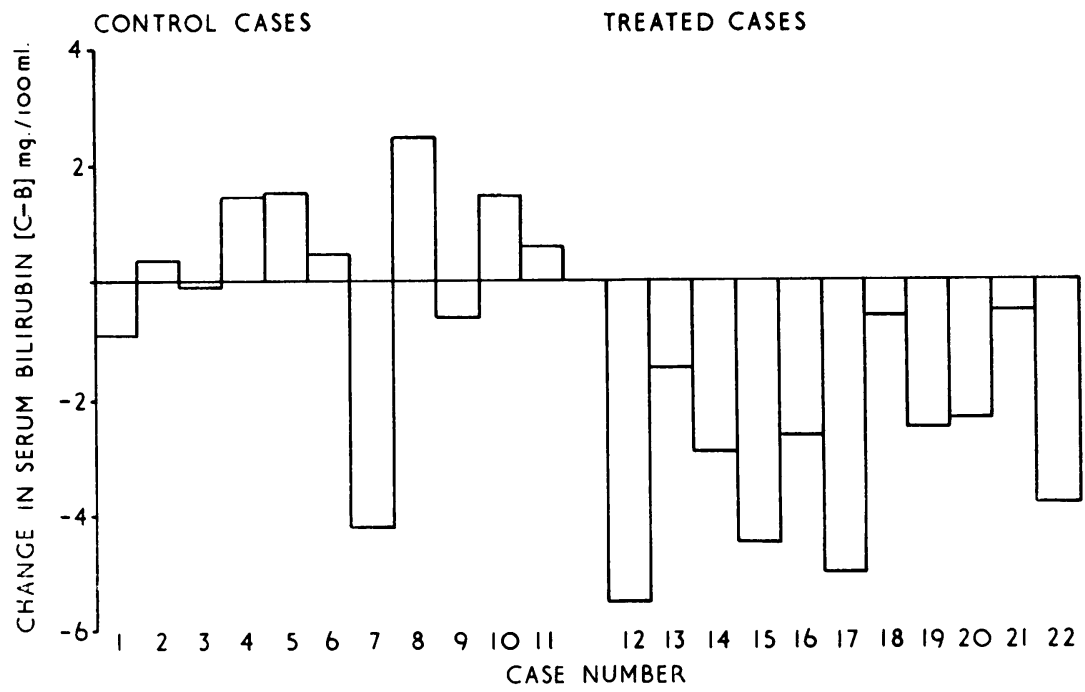

FIG. 2.--Changes in serum bilirubin levels of infants during the 12-hour period between B and C.

fact that the bilirubin level of some cases in the control group fell during this period. The mean fall in bilirubin level $(\mathbf{C}-\mathbf{B})$ in the treated group was $2.9 \mathrm{mg}$. $/ 100 \mathrm{ml}$., whereas the control group showed a mean rise of $0.2 \mathrm{mg} . / 100 \mathrm{ml}$. in the same period. Student's ' $t$ ' test showed that the difference between these two means was highly significant ( $p<0.001)$. After the end of light treatment the serum bilirubin level of some cases showed a rebound. This is indicated in Table 1 by $\mathrm{D}-\mathrm{C}$, but there was no significant difference between the mean values of the two groups.

TABLE 1

RESULTS OF BILIRUBIN ESTIMATIONS, AT 12-HOURLY INTERVALS, ON TREATED AND CONTROL INFANTS

\begin{tabular}{|c|c|c|c|c|c|c|c|c|c|}
\hline \multirow{2}{*}{$\begin{array}{l}\text { Case } \\
\text { No. }\end{array}$} & \multirow{2}{*}{ Wt. (lb.) } & \multirow{2}{*}{$\begin{array}{l}\text { Hours } \\
\text { Light }\end{array}$} & \multirow{2}{*}{ Age (hr.) } & \multicolumn{6}{|c|}{ Serum Bilirubin $(\mathrm{mg} . / 100 \mathrm{ml} .)^{*}$} \\
\hline & & & & Point A & Point B & Point C & Point D & C-B & D-C \\
\hline $\begin{array}{r}1 \\
2 \\
3 \\
4 \\
5 \\
6 \\
7 \\
8 \\
9 \\
10 \\
11\end{array}$ & $\begin{array}{l}\text { Control } \\
3 \cdot 8 \\
2 \cdot 10 \\
7 \cdot 2 \\
5 \cdot 0 \\
4 \cdot 15 \\
5 \cdot 10 \\
6 \cdot 9 \\
7 \cdot 3 \\
3 \cdot 11 \\
4 \cdot 11 \\
5 \cdot 5\end{array}$ & $\stackrel{\text { ases }}{\mathrm{Nil}}$ & $\begin{array}{r}78 \\
77 \\
46 \\
61 \\
83 \\
66 \\
142 \\
62 \\
121 \\
76 \\
92\end{array}$ & $\begin{array}{l}14 \cdot 4 \\
13 \cdot 4 \\
12 \cdot 4 \\
13 \cdot 7 \\
14 \cdot 0 \\
12 \cdot 5 \\
15 \cdot 1 \\
13 \cdot 7 \\
13 \cdot 0 \\
12 \cdot 1 \\
12 \cdot 6\end{array}$ & $\begin{array}{l}15 \cdot 8 \\
14 \cdot 7 \\
14 \cdot 9 \\
16 \cdot 6 \\
15 \cdot 0 \\
13 \cdot 5 \\
16 \cdot 2 \\
14 \cdot 6 \\
15 \cdot 1 \\
13 \cdot 1 \\
13 \cdot 3\end{array}$ & $\begin{array}{l}15 \cdot 0 \\
15 \cdot 0 \\
14 \cdot 8 \\
18 \cdot 1 \\
16 \cdot 6 \\
14 \cdot 0 \\
12 \cdot 0 \\
17 \cdot 0 \\
14 \cdot 4 \\
14 \cdot 6 \\
13 \cdot 9\end{array}$ & $\begin{array}{l}11 \cdot 2 \\
15 \cdot 0 \\
14 \cdot 9 \\
18 \cdot 1 \\
16 \cdot 9 \\
\overline{14 \cdot 5} \\
15 \cdot 4 \\
14 \cdot 4 \\
\overline{13 \cdot 1}\end{array}$ & $\begin{array}{r}0.8 \\
0.3 \\
-0.1 \\
1.5 \\
1.6 \\
0.5 \\
-4 \cdot 2 \\
2 \cdot 4 \\
-0.7 \\
1.5 \\
0.6\end{array}$ & $\begin{array}{l}-3 \cdot 8 \\
0 \\
0.1 \\
0 \\
0.3 \\
\overline{2} \cdot 5 \\
-1 \cdot 6 \\
0 \\
-\overline{0} \cdot 8\end{array}$ \\
\hline Mean & $5 \cdot 2$ & & 82 & $13 \cdot 4$ & $14 \cdot 8$ & $15 \cdot 0$ & $14 \cdot 8$ & $0 \cdot 2$ & -0.4 \\
\hline $\begin{array}{l}12 \\
13 \\
14 \\
15 \\
16 \\
17 \\
18 \\
19 \\
20 \\
21 \\
22\end{array}$ & \begin{tabular}{l}
\multicolumn{1}{c}{ Treated } \\
$5 \cdot 2$ \\
$6 \cdot 14$ \\
$3 \cdot 3$ \\
$3 \cdot 9$ \\
$3 \cdot 2$ \\
$4 \cdot 10$ \\
$4 \cdot 5$ \\
$7 \cdot 3$ \\
$5 \cdot 0$ \\
$6 \cdot 10$ \\
$8 \cdot 7$
\end{tabular} & $\begin{array}{c}\text { ases } \\
9 \\
9 \\
9 \\
7 \frac{1}{2} \\
9 \\
9 \\
9 \frac{1}{2} \\
7 \\
9 \\
8 \\
9 \\
9\end{array}$ & $\begin{array}{r}103 \\
67 \\
79 \\
57 \\
109 \\
83 \\
80 \\
70 \\
89 \\
70 \\
70\end{array}$ & $\begin{array}{l}14 \cdot 1 \\
12 \cdot 7 \\
13 \cdot 8 \\
12 \cdot 6 \\
16 \cdot 1 \\
13 \cdot 1 \\
12 \cdot 2 \\
16 \cdot 4 \\
12 \cdot 1 \\
13 \cdot 1 \\
12 \cdot 5\end{array}$ & $\begin{array}{l}15 \cdot 4 \\
13 \cdot 7 \\
17 \cdot 2 \\
16 \cdot 4 \\
18 \cdot 8 \\
14 \cdot 0 \\
16 \cdot 1 \\
18 \cdot 7 \\
13 \cdot 6 \\
13 \cdot 8 \\
13 \cdot 3\end{array}$ & $\begin{array}{r}9 \cdot 9 \\
12 \cdot 2 \\
14 \cdot 3 \\
11 \cdot 9 \\
16 \cdot 1 \\
9 \cdot 0 \\
15 \cdot 4 \\
16 \cdot 1 \\
11 \cdot 2 \\
13 \cdot 2 \\
9 \cdot 5\end{array}$ & $\begin{array}{r}10 \cdot 1 \\
9 \cdot 5 \\
14 \cdot 9 \\
11 \cdot 8 \\
14 \cdot 2 \\
10 \cdot 8 \\
15 \cdot 0 \\
\overline{11 \cdot 1} \\
13 \cdot 5 \\
7 \cdot 4\end{array}$ & $\begin{array}{l}-5.5 \\
-1.5 \\
-2.9 \\
-4.5 \\
-2.7 \\
-5.0 \\
-0.7 \\
-2.6 \\
-2.4 \\
-0.6 \\
-3.8\end{array}$ & $\begin{array}{r}0.2 \\
-2.7 \\
0.6 \\
-0.1 \\
-1.9 \\
1.8 \\
-0.4 \\
-\overline{0} \cdot 1 \\
0.3 \\
-2 \cdot 1\end{array}$ \\
\hline Mean & $5 \cdot 4$ & 8 & 80 & $13 \cdot 5$ & $15 \cdot 5$ & $12 \cdot 4$ & $11 \cdot 8$ & $-2 \cdot 9$ & -0.4 \\
\hline
\end{tabular}

* The timing of points A, B, C, D, is given in the text, and illustrated in Fig. 1. 
At the age of 1 year the treated infants were developing normally and showed no signs of neurological or other disorder.

Gunn Rats. The initial plasma bilirubin concentrations of the Gunn rats ranged from $6 \cdot 7$ to $12 \cdot 6$ $\mathrm{mg} . / 100 \mathrm{ml}$., all the pigment being in the unconjugated form. Exposure to blue light caused an immediate and significant fall in the bilirubin levels of all animals, as shown in Fig. 3. Further slight decreases were observed on subsequent days, but in no animal

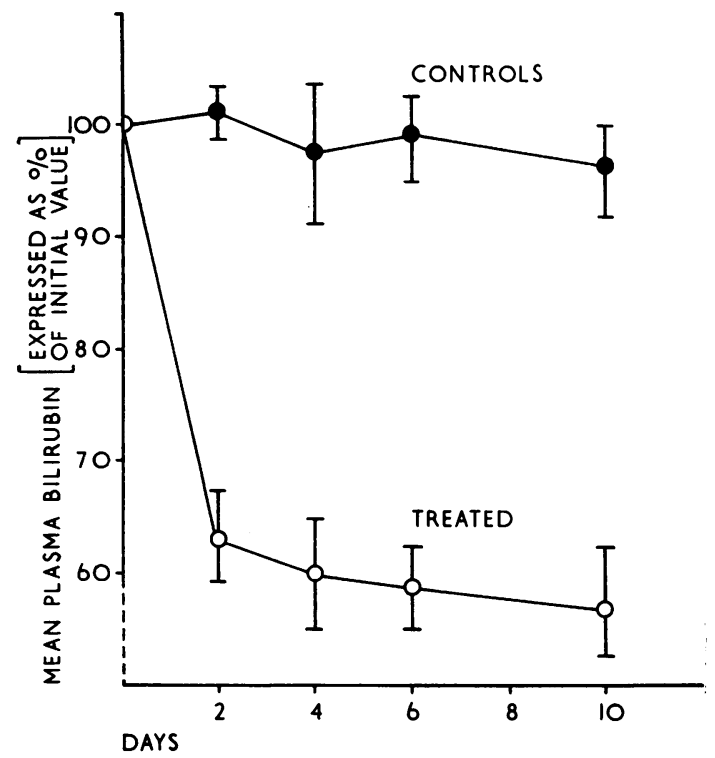

Fig. 3.-Effect of blue light on the mean plasma bilirubin levels of Gunn rats. The standard errors of the means are indicated by vertical bars.

was it possible to reduce the plasma concentration to less than $36 \%$ of the initial value, even when exposure was continued for as long as 20 days. Similar changes were observed in female rats. No detectable ill effects due to the light were observed: the animals ate well, maintained their body weight, and suffered no apparent deterioration of vision.

Mitochondria. Results of typical experiments with liver and brain mitochondria are given in Table 2. These show that untreated bilirubin uncoupled oxidative phosphorylation, as demonstrated by a reduction in the $\mathrm{P} / \mathrm{O}$ ratio. Light treatment of bilirubin, sufficient to reduce the concentration to about half its original value, restored the $\mathrm{P} / \mathrm{O}$ ratio to that of the control flask. After 32 hours irradia-
TABLE 2

EFFECT OF BILIRUBIN AND LIGHT TREATED BILIRUBIN ON THE PHOSPHORUS/OXYGEN (P/O) RATIO OF RAT LIVER AND BRAIN MITOCHONDRIA, IN A MEDIUM CONTAINING $10 \%$ SERUM

\begin{tabular}{|c|c|c|c|c|}
\hline \multirow[b]{2}{*}{$\begin{array}{l}\text { Addition to } \\
\text { Flask }\end{array}$} & \multicolumn{2}{|c|}{ Liver Mitochondria } & \multicolumn{2}{|c|}{ Brain Mitochondria } \\
\hline & $\begin{array}{l}\text { Bilirubin } \\
\text { Concen- } \\
\text { tration in } \\
\text { Medium } \\
\text { (mg.l } \\
100 \mathrm{ml} .)\end{array}$ & $\begin{array}{c}\mathrm{P} / \mathrm{O} \\
\text { Ratio }\end{array}$ & $\begin{array}{l}\text { Bilirubin } \\
\text { Concen- } \\
\text { tration in } \\
\text { Medium } \\
(\mathrm{mg} . / \\
100 \mathrm{ml} .)\end{array}$ & $\begin{array}{c}\mathbf{P} / \mathbf{O} \\
\text { Ratio }\end{array}$ \\
\hline \multirow{3}{*}{$\begin{array}{l}\text { Nil } \\
\text { Bilirubin stored in dark } \\
\text { at } 22^{\circ} \mathrm{C} \text { for } 32 \text { hours } \\
\text { Bilirubin, light treated } \\
\text { at } 26^{\circ} \text { C. for } 32 \text { hours }\end{array}$} & Nil & $1 \cdot 54$ & Nil & $1 \cdot 47$ \\
\hline & $34 \cdot 6$ & 0.54 & $35 \cdot 4$ & 0.85 \\
\hline & 18.0 & 1.59 & $17 \cdot 4$ & $1 \cdot 60$ \\
\hline
\end{tabular}

Each value represents the mean of duplicate estimations. $\quad \mathrm{P} / \mathrm{O}$ refers to the ratio of $\mu$ moles of inorganic phosphate esterified per $\mu$ atom of oxygen consumed.

tion the bilirubin concentration had fallen to less than $20 \mathrm{mg} . / 100 \mathrm{ml}$., and other experiments (P. S. Lord, 1965, unpublished results), which did not involve irradiation, showed that this concentration, in a solution containing fresh human serum, did not uncouple oxidative phosphorylation. The products of bilirubin irradiation have failed to show any effect on oxidative phosphorylation in the experiments described here.

\section{Discussion}

These experiments show clearly that the serum bilirubin levels of both jaundiced infants and Gunn rats can be reduced by irradiation with blue light.

All the 11 irradiated infants described in this paper showed a decrease in serum bilirubin level, averaging $2.9 \mathrm{mg}$. $/ 100 \mathrm{ml}$., after approximately 8 hours of treatment, and this fall was significantly different from that of the control group. Cremer et al. (1958) found that serum bilirubin concentrations fell in all 9 premature infants with jaundice who were treated with artificial blue light, and Franklin (1958) obtained similar results in 8 out of 10 treated cases. Blondheim et al. (1962b), however, considered the method disappointing, and noted that serum levels rose slightly in 3 out of 8 cases treated with light of an unspecified type.

Light treatment of jaundiced infants can only be recommended if the products of irradiation are less toxic than bilirubin. The toxic effect of bilirubin on tissue respiration has previously been demonstrated by its inhibition of oxygen uptake by brain (Day, 1954) and by the uncoupling of oxidative phosphorylation in both liver and brain mitochondria (Zetterström and Ernster, 1956; Biesold et al., 1962). The experiments reported here, in which mitochondria were incubated with irradiated solutions of bilirubin, 
indicate that the products of this photodecomposition have no effect on oxidative phosphorylation, whereas untreated bilirubin was highly active.

The nature of these products is unknown, though Cremer et al. (1958) and Brodersen and Vind (1963) obtained evidence that biliverdin was formed when jaundiced serum was irradiated with blue light. Most reports have indicated that this substance has no effect on tissue respiration (Day, 1956; Ebnöter and Vest, 1959) or oxidative phosphorylation (Zetterström and Ernster, 1956), though Biesold et al. (1962) found an inhibition of respiration due to biliverdin. Larson, Evans, and Watson (1947) described the presence of biliverdin in the serum of jaundiced adults, and did not associate this with any toxic effects. Blondheim, Lathrop, and Zabriskie $(1960,1962 a)$ studied the spectral changes that occur when jaundiced serum is exposed to light, and found that the products were more diffusible than bilirubin. Other workers have shown that they are more polar and therefore more water-soluble than bilirubin (Ostrow, Hammaker, and Schmid, 1961 ; Brodersen and Vind, 1963). Blondheim et al. (1962b) inferred from this that they might cross the blood brain barrier and be potentially toxic. But the toxicity of bilirubin has been attributed to its fat solubility, and it seems probable that the water-soluble products would, therefore, be less toxic, and also more easily excreted. From our results, there was no evidence that the products of light treatment were toxic to infants or rats, and the loss of toxicity to mitochondria after irradiation of bilirubin was striking.

The usefulness of exposure to light as a treatment for hyperbilirubinaemia in an individual case will depend on the rate at which the serum bilirubin is rising, upon the duration of treatment, and probably on other factors. This method provides a possible alternative to exchange transfusion in selected cases of 'physiological' jaundice in both premature and full-term infants, who require treatment. In such cases the rate of rise of serum bilirubin is usually slow, allowing time for lengthy exposure to light. It might also have a limited application in the treatment of some mildly affected cases of haemolytic disease, where the serum bilirubin is only rising slowly. In more severe cases, which have been given an initial exchange transfusion, light treatment could occasionally be considered as an alternative to a difficult second or third transfusion. It should, however, be emphasized that light treatment is ineffective when the serum bilirubin level is rising rapidly, and it follows that the method should not be considered unless serum bilirubin determinations are readily available.

\section{Summary}

A group of 11 infants with 'physiological' jaundice, chosen by random selection, have been treated by irradiation with an artificial blue light. The serum bilirubin concentration of the treated infants fell by an average of $2.9 \mathrm{mg} . / 100 \mathrm{ml}$. during treatment, and this was significantly greater than the change in bilirubin level in a similar untreated group of infants.

Jaundiced Gunn rats were exposed to a similar light source for 10 days, and their plasma bilirubin concentrations fell significantly when compared with an untreated control group of rats.

Bilirubin in the presence of serum uncouples oxidative phosphorylation of rat liver and brain mitochondria. Photodecomposition of the bilirubin destroys this uncoupling effect, and the products of the reaction showed no effect on oxidative phosphorylation.

These results show that treatment of a jaundiced subject with blue light can reduce the serum bilirubin level, and that there is no evidence that the products of light treatment are toxic.

We are grateful to Mr. P. W. Perryman for advice in the construction of the light cradle and for valuable information about its use; to the General Electric Co., Ltd., for information about the light source used; and to Dr. B. H. Billing, Professor G. H. Lathe, and Dr. C. Toothill for their helpful advice and criticism of this work.

\section{REFERENCES}

Aldridge, W. N. (1957). Liver and brain mitochondria. Biochem. J., 67, 423.

Biesold, D., Liebold, F., and Theile, H. (1962). Die Wirkung von Bilirubin auf den Hirnstoffwechsel in vitro. Acta biol. med. germ., 9, 652.

Blondheim, S. H., Lathrop, D., and Zabriskie, J. (1960). A diffusible bilirubin(oid) produced by exposure of jaundiced serum to light. Gastroenterology, 38, 798.

- - $\longrightarrow$, and Zabriskie, J. (1962a). Effect of light on the absorption spectrum of jaundiced serum. J. Lab. clin. Med., 60, 31.

—, Zabriskie, J., and Lathrop, D. (1962b). Kernicterus and prematurity. Brit. med. J., 1, 52.

Brodersen, R., and Vind, I. (1963). Chloroform extraction of serum bilirubin in relation to its binding to proteins. Scand.J. clin. Lab. Invest., 15, 107.

Christie, G. S., Judah, J. D., and Rees, K. R. (1953). Cofactor and metal requirements of brain mitochondria. Proc. roy. Soc. B 141, 523.

Cremer, R. J., Perryman, P. W., and Richards, D. H. (1958). Influence of light on the hyperbilirubinaemia of infants. Lancet, 1, 1094.

Day, R. L. (1954). Inhibition of brain respiration in vitro by bilirubin. Reversal of inhibition by various means. Proc. Soc. exp. Biol. (N.Y.), 85, 261.

- (1956). Kernicterus: further observations on the toxicity of heme pigments. Pediatrics, 17, 925.

Ebnöter, P., and Vest, M. (1959). Zum Problem der Hyperbilirubinämie und des Kernikterus. Ann. paediat. (Basel), 193, 279.

Ernster, L., Herlin, L., and Zetterström, R. (1957). Experimental studies on the pathogenesis of kernicterus. Pediatrics, 20, 647.

Ferreira, H. C., Berezin, A., Barbieri, D., and Larrubia, N. M. (1960a). A super iluminação no tratamento das hiperbilirrubinemias do recém-nascido. Rev. Ass. méd. bras. 6201 
(1960b). A super-iluminação na hiperbilirrubinemia do recém-nascido. J. Pediát. (Rio de J.), 25, 12. - and $-(1960 \mathrm{c})$. A super-iluminação na hiperbilirrubinemia do recém-nascido. An. bras. Ginec., 49, 147.

—, Cardim, W. H., and Mellone, O. (1960). Fototerapia: novo recurso terapêutico na hiperbilirrubinemia do recém-nascido. J. Pediát. (Rio de J.), 25, 347.

Fiske, C. H., and Subbarrow, Y. (1925). The colorimetric determination of phosphorus. J. biol. Chem., 66, 375.

Franklin, A. W. (1958). Influence of light on the hyperbilirubinaemia of infants. Lancet, 1, 1227.

King, E. J., and Coxon, R. V. (1950). Determination of bilirubin with precipitation of the plasma proteins. J. clin. Path., 3, 248.

Lardy, H. A., and Wellman, H. (1952). Oxidation phosphorylations: role of inorganic phosphate and acceptor systems in control of metabolic rates. J. biol. Chem., 195, 215.

Larson, E. A., Evans, G. T., and Watson, C. J. (1947). A study of the serum biliverdin concentration in various types of jaundice. J. Lab. clin. Med., 32, 481.

Lathe, G. H., and Ruthven, C. R. J. (1958). Factors affecting the rate of coupling of bilirubin and conjugated bilirubin in the van den Bergh reaction. J. clin. Path., 11, 155

$\longrightarrow$, and Walker, M. (1958). The synthesis of bilirubin glucuronide in animal and human liver. Biochem. J., 70, 705.

Malloy, H. T., and Evelyn, K. A. (1937). The determination of bilirubin with the photoelectric colorimeter. J. biol. Chem., 119, 481.
Mellone, O. (1960). Tratamento da hiperbilirrubinemia do recémnascido por foco de luz intensa. Rev. paul. Med., 57, 47.

Ostrow, J. D., Hammaker, L., and Schmid, R. (1961). The preparation of crystalline bilirubin-C14. J. clin. Invest., 40, 1442.

Peluffo, E., Beltran, J. C., Malinger, A., Giguens, W., Vila Vidal, P. and Lorenzo de Ibarreta, J. (1962). Luminoterapia en las ictericias del recien nacido. Arch. Pediat. Urug., 33, 98.

Rozdilsky, B., and Olszewski, J. (1961). Experimental studies of the toxicity of bilirubin in newborn animals. J. Neuropath. exp. Neurol., 20, 193.

Trolle, D. (1964). Incidence and possible relation to athetosis of neonatal jaundice of unknown aetiology. Arch. Dis. Childh., 39, 85 .

Wood, B. S. B., Culley, P. E., Waterhouse, J. A. H., and Powell, D. J. (1962). Factors influencing neonatal jaundice. ibid., 37, 371.

Zetterström, R., and Ernster, L. (1956). Bilirubin, an uncoupler of oxidative phosphorylation in isolated mitochondria. Nature (Lond.), 178, 1335.

\section{Addendum}

G.E.C. Ltd., have recently informed us that a similar intensity of illumination, but with less heating effect, could be obtained by the use of ten 2 foot 20 watt lamps instead of the eight 40 watt lamps used here. We have not tried this. 